\title{
A Reorganização da Casa da Moeda
}

A confecção do papel moeda é considerada, hoje em dia, em função de ưm problema da mais alta relevância: o da segurança nacional.

Admite-se - e as vozes discordantes são muito raras - que a segurança nacional não estará integralmente resguardada com - simples privilégio estatal da cunhagem da moeda, já que esta medida precisa ser suplementada pela posse dos recursos técnicos que a tornem efetiva e completa.

Os abalos que as fortes emissões de notas falsas produziram na economia de alguns países durante a última guerra, quando se demonstrou que o "flanco monetário" era tão importante quanto os campos de batalha militar, veio acrescer o interêsse pelo estudo da confecção da moeda como problema de segurança nacional.

Há hoje por todo o mundo uma diligente preocupação no sentido de emprestar ao fabrico da moeda o máximo de garantia, pondo-se ao serviço dêsse objetivo as melhores recomendações da técnica, a mais apurada mão de obra e os materiais testados e aprovados com o mais extremo rigor.

Os exemplos da Áustria e da Alemanha são recentes e oferecem ao mundo duas primorosas instalações especializadas na impressão de valores; e aqui mesmo na América do Sul, a Argentina, o Chile e a Colômbia, mediante a execução de projetos de grande envergadura, assumem posição de vanguarda no ramo das artes gráficas especializadas na preparação de moeda papel.

No Brasil só há bem pouco tempo começamos a preocuparnos com o problema. Habituados a confiar ao estrangeiro o fabrico de nosso papel moeda, não nos demos conta do extraordinário progresso das artes gráficas especializadas e, por isso mesmo, não nos aparelhamos para usar suas conquistas como elemento de proteção de nesso "front monetário". 
Assim, face a um fenômeno típico dos tempos que correm: a limitação crescente do uso da moeda metálica e o uso cada vez mais amplo da moeda papel, nosso país vai ficando para trás.

A modificação dêsse quadro não é tão fácil, como pode parecer à primeira vista, por isso que nêle intervêm elementos de ordem histórica, em tôrno dos quais se constituiu uma tradição de traba1ho capaz de forte resistência ao espirito de renovação.

Desde 1694, quando foi fundada, a Casa da Moeda tem sido um misto de repartição industrial e de Liceu de Belas Artes. Estas últimas, apesar de um tanto superestimadas, são de fato indispensáveis aos artesanatos básicos da cunhagem e da impressão, os quais, além das operações mecânicas, não pođem prescindir do trabalho artístico da concepção, do desenho, da modelagem e da gravura.

Resultam daí exigências de formação profissional muito complexas, pois, a par do conhecimento das técnicas dos vários ofícios, suscetivel de ser ministrado e adquirido pelo treinamento, mister se faz também a ocorrência de um fator inato, qual seja a vocação artística.

A tradição de trabalho oriunda da concepção da Casa da Moeda como repartição industrial e centro de cultura artística, tem dificultado a adoção, entre nós, da solução corrente noutros países e que consiste em atribuir aos órgãos encarregados da confecção da moeda apenas a parte industrial da tarefa, deixando aos profissionais particulares o trabalho de natureza artística.

$O$ reajustamento da Casa da Moeda às condições atuais do mercado monetário e aos modernos processos adotados no seu suprimento reclama, em razão dos fatos acima citados, a execução de um completo programa de preparação de novas equipes de trabalho, dentro de um espírito mais acentuadamente industrial.

As exigências dos diferentes ofícios a serem atendidos e o alto grau de responsabilidade pessoal próprio do trato permanente com valores, impõe que nesse programa se conjugue o treinamento pròpriamente dito, através de aulas teóricas e prática de oficina, à seleção com base em demorada observação da conduta no exercício do trabalho.

A fim de atender a êsses objetivos, que são os pontos de partida de uma reforma de caráter mais amplo e de execução prevista 
para futuro próximo, lei especial criou um plano de aprendizagem, visando ao recrutamento de indivíduos jovens, os quais, dentro da própria Casa da Moeda, receberiam a instrução necessária à formação de um artífice integral.

Completado o período de treinamento, o aprendiz ingressaria, pelo processo do concurso, numa das diferentes carreiras profissionais, conforme os seus pendores, ou, se para isso não estivesse habilitado, continuaria em regime de aprendizagem, a fim de tentar novas oportunidades, até atingir a idade limite, quando então seria dispensado por falta da habilitação.

Ao atingir a condição de funcionário, o antigo aprendiz, após um período de treinamento mais avançado, disputaria, ainda pelo processo do concurso, seu enquadramento como Condutor de Serviço, função na qual iria iniciar-se nas práticas da liderança, visando à sua eventual designação para postos de chefia.

Dadas a natureza e finalidades da aprendizagem, o pessoal a ser para ela admitido foi classificado na categoria de extranumerário mensalista e vinculado à administração em caráter precário e por prazo expressamente delimitado, o que tornaria possível, sem maiores complicações, o afastamento dos indivíduos que se mostrassem desinteressados ou carentes de aptidão.

Êsse plano, se tivesse sido iniciado de acôrdo com as previsões feitas ao tempo de sua elaboração, estaria hoje produzindo seus resultados, e a segunda etapa do processo de renovação da Casa da Moeda, consistente na substituição do equipamento obsoleto e quase improdutivo por maquinaria moderna, poderia ser posta em prática.

Infelizmente, porém, a proibição indiscriminada da admissão de extranumerários mensalistas no Serviço Público Federal, por fôrça da última lei de reajustamento dos vencimentos dos funcionários, determinou o fracasso do sistema de aprendizagem, para o qual o D.A.S.P., em prova pública de habilitação, já havia recrutado os primeiros candidatos. Com isso tornou-se inviável a reorganização da linha industrial da Casa da Moeda, por não dispor esta última do elemento humano preparado e adestrado para o emprêgo de certos instrumentos e processos da moderna tecnologia das artes gráficas especializadas. 
Para corrigir essa situação já foram solicitadas as indispensáveis providências, as quais não devem tardar, mesmo porque o grande número de aposentadorias que vêm desfalcando os quadros da Casa da Moeda, ameaçam colocar esta última numa situação que não 1 he permitirá atender, em futuro não muito distante, às necessidades do país, em matéria de selos e moedas metálicas.

Os Poderes Executivo e Legislativo devem encarar com realismo e boa vontade o problema da reorganização da Casa da Moeda, a fim de que o tempo não venha a exigir para êle uma solução heróica. 